\section{Genome unit falls foul of campus politics in India}

[NEW DELHI] A dispute between faculty members and the vice-chancellor of the Jawaharlal Nehru University in New Delhi has blocked the establishment of a National Centre for Plant Genome Research on its campus. The move has embarrassed the Department of Biotechnology (DBT), which only a month ago had announced the launch of the centre with an initial investment of US\$7 million.

According to the department's secretary, Manju Sharma, the university was chosen because it already had a genetic engineering unit and a centre for plant molecular biology - both funded by the department. The plan was to merge these units with the national centre to create a strong centre for coordinating plant genetics research countrywide.

But opposition to the merger has come from the university's 400-member staff association, which complains that the creation of a non-teaching institute such as the planned centre would not benefit the university's students or researchers, and will only absorb funds that might otherwise come to the university from government.

At the centre of the controversy is vicechancellor Asis Datta, a well known plant molecular biologist. The staff association argued that Datta reached the deal with DBT without the sanction of the academic council, and acted in "haste and secrecy" in transferring 15 acres for the centre in violation of a ban on the donation of university land to other institutions. It claims that the proposed centre is linked to the vice-chancellor's own field of interest, and that he and other select members of faculty "will be the only beneficiaries".

But Datta says the matter has been discussed and approved by the university executive council, of which he is the chairman. $\mathrm{He}$ says that merger of the two existing units both facing closure in three months as their research projects come to an end - with the planned research centre was the best way to ensure continuity of jobs for the staff. He also argues that the new centre would work closely with university faculty members, and form part of a unique network of advanced plant genetic research in the country.

The dispute between the vice-chancellor and faculty members (who have been joined by the students' union) has now forced the ministry of education, which controls the university, to put plans for the new centre on hold. Admitting the setback, Sharma says her department is not insisting on an autonomous institute and will be open to "alternative suggestions" for establishing the centre.

K.S.Jayaraman

\title{
US 'split' over support for research project database
}

[WASHINGTON] The US government should provide \$3 million over three years to support a database that has been developed to track detailed information on all publicly supported research and development, according to a panel set up by the National Science Foundation (NSF) to assess the future of the database.

Rand Corporation, which set up the database for the government, has threatened to pull the plug on it on 1 March if does not get paid to maintain the system, which costs at least \$1 million a year more to run than it generates from user fees.

But as that deadline nears it remains unclear where the government will find the money to run the database, which is known as RaDiUS (for Research and Development in the United States). Some government agencies are said to be reluctant to support a management tool which they fear could be used to criticize their programmes and attack their budgets.

The NSF panel was chaired by Irwin Feller, head of the economics department at Pennsylvania State University. It concludes that "despite its weaknesses, it is extremely important that RaDiUS be continued," and warns: "If RaDiUS died because of a lack of funding, this would probably also kill any hope of any other such system for a number of years."

Alarmed at such a prospect, the staff of Representative James Sensenbrenner (Republican, Wisconsin), chair of the House Science Committee, and Senator Jeff Bingaman (Democrat, New Mexico) - two important supporters of science in Congress
- have been closely monitoring the fate of RaDiUS.

But a meeting last week between the NSF, the Office of Science and Technology Policy (OSTP) and the Office of Management and Budget $(\mathrm{OMB})$ failed to make much progress in determining who should pay for the database. RaDiUS lost \$1.4 million last year after a plan to raise money from users of the system fell flat. According to one official who attended the meeting, NSF is not prepared to pay for the system out of its budget for the current year unless it receives a direct instruction from OSTP to do so.

RaDiUS was developed by Rand with the strong encouragement of Skip Johns, former associate director for technology at OSTP, who wanted the database as a tool to improve coordination of the government's $\$ 70$ billion research and development programmes. But Johns left OSTP in 1996, and officials there are now said to be unsure of its practical value.

According to Paul Herer, a planning adviser at NSF, RaDiUS lacks strong support from potential users in the government. The system suffers, he says, from receiving incomplete data on the activities of some agencies, and from being "unfamiliar" to possible users. "It's ahead of its time a little bit," Herer says.

But Holly Gwinn, chief of staff at OSTP, says that while "nobody considers RaDiUS to be a perfect system", its shortcomings would be "addressable" if the government decided that the database was worth having. "We've been working with $\mathrm{OMB}$ to see what the value added is," she says. "We haven't reached a consensus on this." ColinMacilwain

\section{Kennedy backed on use of tobacco money}

[WASHINGTON] Senator Edward Kennedy (Democrat, Massachusetts), a long-time supporter of medical research funding, last week received the backing of advocates of biomedical research for a bill that would direct billions of dollars raised from tobacco companies to US biomedical research.

At a press conference in Washington DC last Friday (23 January), almost a hundred medical research societies endorsed the Kennedy bill, which would levy a tax of $\$ 1.50$ on every packet of cigarettes.

Just under 43 cents of that would be used to support biomedical and other research at the National Institutes of Health, the National Science Foundation and other federal agencies.

Kennedy estimates that research would receive an extra $\$ 8$ to $\$ 10$ billion each year

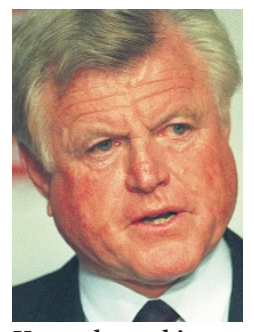

Kennedy: seeking boost for research.

bill funded research "at a level consistent with devastation of the cancer caused by tobacco use".

The bill is one of four to be introduced in the Senate as starting points for legislation codifying a $\$ 368.5$ billion settlement with the tobacco industry. 